\title{
Demographic Patterns in the Åland Islands, Finland, 1750-1900
}

\author{
JAMES H. MIELKE ${ }^{1}$ \\ KARI J. PITKÄNEN ${ }^{2}$ \\ LYNN B. JORDE ${ }^{3}$ \\ JOHAN O. FELLMAN ${ }^{4}$ \\ ALDUR W. ERIKSSON ${ }^{5}$
}

\section{Introduction}

Both Finnish and Swedish source materials for studying demographic history are of exceptional quality. Providing detailed information both on vital events and on population size and structure since 1749 , these statistics form an excellent basis for investigating demographic developments in the past. Information for the population statistics consists of two sets of parish records of the Lutheran church, the records of births (baptisms), marriages, and deaths (burials), and the so-called communion books (register of the parishioners). The former type of records does not extend as far back in time as in many European countries because in most parishes record keeping did not start until the late seventeenth or early eighteenth century. This lack of time depth is, however, made up for by the fact that the contents of the records, especially from the mid-eighteenth century onward, are of good quality and exceptionally detailed. For example, the records of deaths usually report the date of death and burial, the name of the individual, his or her occupation, the place of residence at death, the age at death, and the cause of death. The other set of records, the communion books, provide a detailed listing of the size and composition of each household along with other valuable supplemental information.

Three years ago we began to computerize all of the information contained in the birth, marriage, and death records of the Alland Islands, Finland, from 1750 to 1900 . Aland was chosen as a site for detailed future research on historical demography because of our understanding of the genetics and population structure of the archipelago (e.g., see Eriksson, 1973; Eriksson et al, 1973 a, b; Jorde et al, 1982), its history, size, and unique geographic location. Aland is situated between Sweden and mainland Finland and is bounded to the south by the Baltic Sea and to the north by the Gulf of Bothnia (Figure 1). Even though the archipelago consists of about 6,600 islands, only 158 of them were inhabited at the beginning of the twentieth century (Jaatinen, 1960). The province of Åland encloses about 10,000 square kilometers, of which only 1,450 square kilometers compose the land area (Sjölund et al, 1972). Although the inhabitants of Alland have had lively connections with both Sweden and mainland Finland (and even with other regions surrounding the Baltic

1 Department of Anthropology, University of Kansas, Lawrence, USA.

2 Department of Economic and Social History, University of Helsinki, Finland.

${ }^{3}$ Department of Human Genetics, University of Utah School of Medicine, Salt Lake City, USA.

4 Samfundet Folkhälsans Genetiska Institut, Populationsgenetiska avdelningen, Helsinki, Finland.

5 Faculteit der Geneeskunde, Anthropogenetisch Instituut, Vrije Universiteit, Amsterdam; The Netherlands and Samfundet Folkhälsans Genetiska Institut, Populationsgenetiska avdelningen, Helsinki, Finland. 
F i g u r e 1. Map showing the location of Aland and the division into church parishes or kommuner.

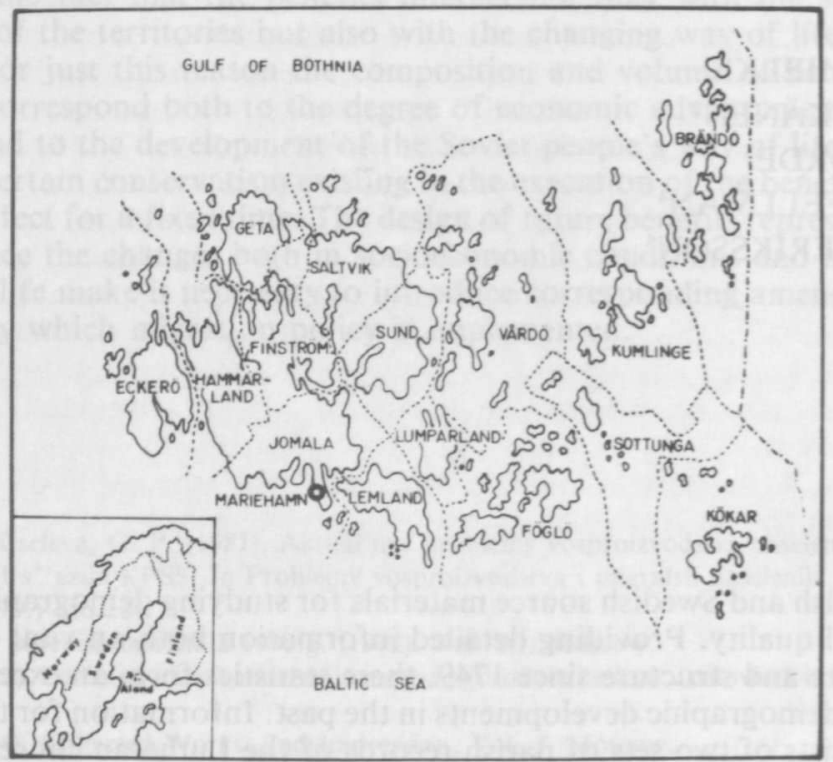

Sea) the special location of the archipelago has meant that it has been relatively isolated from other areas. In fact, the population living in the outer islands (e.g., Sottunga and Kökar) has been relatively isolated from the rest of the archipelago. This insularity is partly due to the difficulties in travelling and the fact that the region has been divided into several administrative units (formerly church parishes, presently kommuner). Since the mid-sixteenth century Åland has been divided into 15 parishes scattered around the archipelago (Figure 1). In addition to these rural parishes, a sixteenth urban kommun, the town of Mariehamn, was founded in 1861. The average population size of the administrative units has always been small. In the 1720 s the estimated population size was only 6,000 individuals. By 1750 Alland's population had increased to about 9,000 individuals. Growth continued, with fluctuations, and by the turn of the twentieth century the archipelago had slightly more than 20,000 inhabitants.

Due to the special ecological setting of the archipelago the investigation of its population history can provide some interesting results and insights. The database, which will eventually include all the information contained in the birth, marriage, and death records, from 1750 to 1950 , will provide an excellent source for aggregate and individual level studies. In fact, the vital events records and communion books have already been used for studying twinning rates (Eriksson, 1973), marital migration, and population structure (Eriksson et al, 1973 a, b; Mielke et al, 1976, 1982), genetic structure (Jorde et al, 1982), infant mortality (Trapp et al, 1983), household and family structure (Nerdrum, 1976, 1978; Devor, 1979), and smallpox mortality (Mielke et al, 1984; Jorde et al, 1987). For all such studies dealing with special topics of the Alandic demographic history, a need for information concerning general, overall demographic patterns in the islands during the last few centuries is obvious. To date, however, no such study exists. The purpose of this paper is to provide some knowledge concerning Alland's population history from the mid-eighteenth century to the turn of the twentieth century. 
In this study we will examine the levels and variation in population growth in Alland, concentrating on the fertility and mortality patterns. The corresponding national data for Finland and Sweden are used for comparison. We will also detail the yearly variation in the vital events (crude birth, marriage, death rates) and analyze the years of »crisis» behavior in these time series. Thus, this paper will examine general trends in the population dynamics of Åland which will be used as a background for more detailed studies on special topics in historical demography.

\section{Materials and methods}

Starting in 1749 Lutheran ministers were required to maintain records of their parishioners on two statistical forms: the so called Population Tables (census) and the Population Change Tables. These records (summary tables for Aland) are the primary sources for this research. The Population Tables contain age, marital status, and occupational structure of the parish or region, while the Population Change Tables record numbers of births, marriages, and deaths. Starting in 1774 the Population Change Tables also give the ages of women who gave birth. For further discussion of the contents of these records, see Pitkänen (1977, 1980, 1984).

Life expectancy at birth $\left(\mathrm{e}_{\mathrm{o}}\right)$ for the later time periods $(1876-1900)$ was estimated using the computer program TWOCN (MCPDA, 1986). All other life tables were empirically derived. The program estimates life expectancy based upon two population censuses given in five-year age intervals and model life tables. South model tables of Coale-Demeny (1983) were used because they fit the infant mortality patterns much better than either the north or west tables. The technique assumes that change between census dates is due solely to births and deaths. Empirically derived tables were not calculated for these later periods because the communion books often retained emigrants and non-residents after their departure from the parish. Inclusion of these individuals has resulted in overestimates of population sizes. This in turn causes underestimation of all demographic rates during the last decades of the 19th century when information derived from the Population and Population Change Tables is used (see Pitkänen, 1980, 1986). The estimated life expectancies serve as rough estimates until we are able to do the necessary corrections on the original data.

To examine crisis years an »Index of Extreme Behavior» was constructed following the work of Gutmann (1980), except that we used crude rates instead of raw totals of births, marriages, and deaths. Before employing regression, we eliminated the extreme outliers during the $1808-09$ war period when mortality was very high. The formula for the Index is:

$$
\mathrm{I}(\mathrm{x})=\mathrm{A}(\mathrm{x}) / \mathrm{Y}(\mathrm{x})
$$

where:

$\mathrm{I}(\mathrm{x})=$ index value for year $\mathrm{x}$

$\mathrm{A}(\mathrm{x})=$ actual value for year $\mathrm{x}$

$\mathrm{Y}(\mathrm{x})=$ predicted value for year $\mathrm{x}$ using linear regression, $\mathrm{Y}(\mathrm{x})=\mathrm{a}+\mathrm{bx}$

After the estimates of $\mathrm{Y}(\mathrm{x})$ were obtained, the original values for the $1808-1809$ period were reinserted for comparison.

To examine the relationship between Åland-Finland and Åland-Sweden in vital events rates, sliding cross-correlation analysis was used (see Chatfield, 1984; Gottman, 1981). A cross-correlation is a simple modification of the product-moment correlation. Instead of calculating a single correlation, $\mathrm{r}$, between time series $\mathrm{x}_{t}$ and series $y_{1}$, a vector of correlations, $r(k)$, is calculated between $x_{t-k}$ and $y_{t}$.

A time series is denoted as $x_{t}$, where $t=1, \ldots, N(N$ is the number of data points in the time series). The lag term, $\mathrm{k}$, can take negative values, and $\mathrm{r}(0)$ corresponds to the usual product-moment correlation. Prior to running the correlations, 
all time series were made stationary (if necessary) and prewhitened to eliminate possible spurious correlations due to autocorrelations (McCleary and Hay, 1980).

\section{Results and discussion}

\section{Aland's population growth and its determinants}

During the 18th and 19th centuries Åland's population growth deviated somewhat from the pattern seen in both mainland Finland and Sweden. After the Great Northern War (1700-1721) Finland's population grew rapidly, and from 1721 to 1800 the annual growth rate was approximately $1.3 \%$. Then from 1800 to 1900 the population growth averaged about $1.0 \%$ per annum (Historiallinen tilasto, 1983). For Sweden the annual growth rates during these periods were $0.5 \%$ and $0.8 \%$ respectively (Hofsten and Lundström, 1976). Aland, on the other hand, began in the 1720s with estimated population of 6,000 and grew at an average rate of $0.9 \%$ from 1721 to 1800 and $0.5 \%$ during the 19 th century. This lower growth compared to Finland was to some extent due to the smaller natural increase in the archipelago, but it was also checked by emigration even during the 18th century (Radloff, 1795). Since the late 19th century extensive emigration to Sweden and the United States has led to stagnation and during the 20th century to decreases in the population size.

A graphic representation of the annual growth rates for the Aland Islands compared to Sweden and Finland is provided in Figure 2 (actual rates for Åland are given in Table 1). Most of Alland's rates are between 0.0 and $1.0 \%$, and the overall level of growth is more similar to Sweden than to Finland. The extremely low value $(-2.4 \%)$ in Alland occurred during the five-year period that includes the $1808-09$ war. Little or no growth was evident during the periods $1780-1790$ and $1850-1860$. There are a number of peak growth periods: $1760-1770,1800-1805,1840-45$, and $1860-1900$. However, one has to notice that especially in the 18 th century the population sizes given in the Summary Population Tables are not always accurate, possibly due to missing information from one or several parishes (e.g. in 1785 and 1790). This can be seen when growth in population number is compared to the difference in the number of births and deaths during the inter-census periods.

F i g u r e 2. Growth rates (\%) in Ảland, Sweden and Finland from 1751 to 1900.

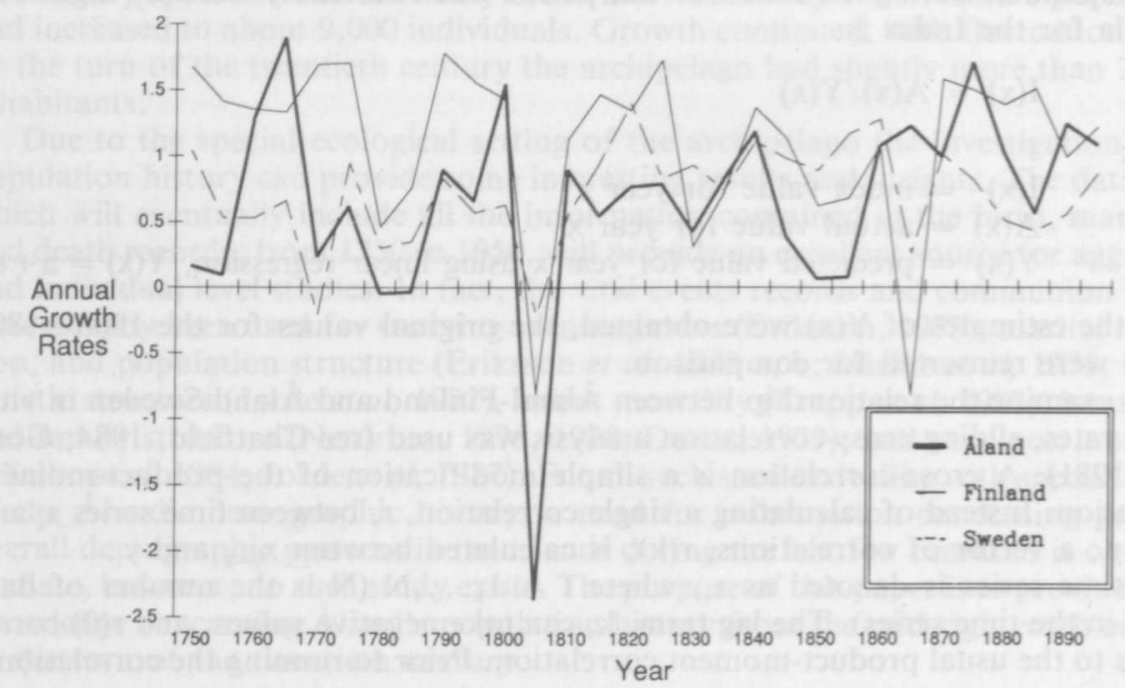


T a b l e 1. Gross reproductive rates (GRR), total fertility rates (TFR), life expectancy at birth $\left(\mathrm{e}_{\mathrm{o}}\right)$ and at age $5\left(\mathrm{e}_{5}\right)$ (both sexes), and growth rates (r) for Aland, Finland.

\begin{tabular}{|c|c|c|c|c|c|}
\hline Year & GRR & TFR & $e_{o}$ & $e_{5}$ & r $(\%)$ \\
\hline $1751-1755$ & $2.98^{*}$ & $6452 *$ & 39.9 & 51.9 & .16 \\
\hline $1756-1760$ & $3.04^{*}$ & $6050^{*}$ & 38.3 & 48.4 & .09 \\
\hline $1761-1765$ & $3.14^{*}$ & $6401^{*}$ & 24.7 & 38.8 & 1.27 \\
\hline $1766-1770$ & $2.71^{*}$ & $5465^{*}$ & 35.5 & 54.7 & 1.89 \\
\hline $1771-1775$ & $2.28^{*}$ & $4481^{*}$ & 31.0 & 50.6 & .23 \\
\hline $1776-1780$ & 2.31 & 4810 & 30.6 & 49.5 & .61 \\
\hline $1781-1785$ & 2.24 & 4616 & 37.7 & 54.9 & -.05 \\
\hline $1786-1790$ & 2.15 & 4342 & 31.9 & 47.1 & -.04 \\
\hline $1791-1795$ & 2.34 & 4673 & 29.8 & 48.7 & .89 \\
\hline $1796-1800$ & 2.41 & 4792 & 35.1 & 53.4 & .65 \\
\hline $1801-1805$ & 2.25 & 4598 & 42.5 & 55.9 & 1.54 \\
\hline $1806-1810$ & 2.08 & 4328 & 24.8 & 36.2 & -2.37 \\
\hline $1811-1815$ & 2.44 & 4930 & 34.9 & 52.1 & .89 \\
\hline $1816-1820$ & 2.21 & 4573 & 34.5 & 50.2 & .54 \\
\hline $1821-1825$ & 2.15 & 4513 & 35.7 & 50.1 & .76 \\
\hline $1826-1830$ & 2.24 & 4536 & 38.5 & 51.5 & .78 \\
\hline $1831-1835$ & 2.07 & 4295 & 36.8 & 48.2 & .42 \\
\hline $1836-1840$ & 2.11 & 4320 & 39.4 & 52.6 & .82 \\
\hline $1841-1845$ & 2.06 & 4197 & 43.4 & 54.8 & 1.18 \\
\hline $1846-1850$ & 1.96 & 3863 & 42.0 & 52.8 & .38 \\
\hline $1851-1855$ & 2.13 & 4331 & 33.2 & 45.9 & .06 \\
\hline $1856--1860$ & 2.02 & 4152 & 36.1 & 45.9 & .07 \\
\hline $1861-1865$ & 2.24 & 4621 & 38.3 & 48.6 & 1.07 \\
\hline $1866-1870$ & 2.17 & 4488 & 44.8 & 51.8 & 1.22 \\
\hline $1871-1875$ & 2.14 & 4379 & 40.8 & 50.2 & .99 \\
\hline $1876-1880$ & 2.14 & 4336 & $59.1 \#$ & $64.0 \#$ & $1.70 !$ \\
\hline $1881-1885$ & 1.93 & 3889 & 47.4 \# & $57.0 \#$ & $1.02 !$ \\
\hline $1886-1890$ & 1.75 & 3580 & $50.5 \#$ & $58.9 \#$ & $.56 !$ \\
\hline $1891-1895$ & 1.64 & 3441 & $46.9 \#$ & $56.7 \#$ & 1.24 ! \\
\hline $1896-1900$ & 1.51 & 3121 & $50.8 \#$ & $59.0 \#$ & $1.08 !$ \\
\hline
\end{tabular}

* Estimated value based upon the mean proportion of women in each age category from the 1775, 1780,1785 , and 1790 census because these figures are not given in earlier census.

\# Calculated from census data using TWOCN (MCPDA 1986). Life expectancy at age five is obtained from model life table given by the program. All other life expectancies were empirically derived.

! Based on official population (census) figures which include most of the emigrated population. Overestimate actual growth.

Consequently, growth rates for five-year periods given in Table 1 (and Figure 2) do not always reflect the actual development. However, during longer periods (from 10 to 15 years) the changes in census population match reasonably well with the natural population growth. On the other hand, the actual growth rates during the last decades of the 19th century are considerably lower due to emigration which is only partly reflected in the official population figures (see above). In general, the growth rates exhibit the same general pattern in each region. One of the most notable differences can be seen during the period 1865-1870, when a famine crisis affected population growth both in Finland and Sweden. In Aland, as well as in many parts of Sweden, mortality increase during the famine was insignificant.

The relative importance of changes in mortality and fertility in affecting the growth rate of a population has been the subject of much debate (Heckscher, 1950; McKeown, 1976, 1978; Wrigley and Schofield, 1981, Hollingsworth, 1969; Habakkuk, 1965). Habakkuk maintains that fertility played a significant role in population growth, but he does not deny that a decrease in mortality occurred in the 18th and early 19th 
centuries in England. McKeown $(1976,1978)$, on the other hand, argues that there were not any major changes in fertility before the latter third of the 19th century and that a decrease in mortality explains the population increase, at least in England. Hollingsworth (1969) also states that fertility was relatively constant and that population change occurred because of changes in mortality. An increase in the population of Sweden during the latter half of the eighteenth century resulted almost immediately after a return to low death rates, suggesting to Heckscher (1950) that mortality was the controlling feature in Swedish population growth. It should be noted that Heckscher did appreciate the diversity displayed among the demographic regimes of Denmark, Norway, Sweden, and Finland, citing not only the similarities but also the differences in each area. In fact, Habakkuk (1965) who feels that fertility may have played the most significant role, suggests that the figures given by Heckscher (1950) show that if the population increase was greater in Finland than in other parts of Scandinavia, it was primarily due to the high birth rates in Finland.

In order to assess the relative importance of changes in mortality and fertility in determining the rate of population growth in Aland, we have employed the methodology of Wrigley and Schofield (1981) and Schofield (1984). We have calculated gross reproductive rates (GRR) and expectation of life at birth $\left(\mathrm{e}_{\mathrm{o}}\right)$ for 5-year periods from 1750 to 1900 (Table 1). Since these two measures are not influenced by changes in the population's age structure, they are good measures to use to examine the temporal changes in both fertility and mortality. The gross reproductive rate is a special case of the total fertility rate (TFRs are also provided in Table 1) which measures the number of daughters a cohort of women will bear, assuming they all

$\mathrm{Fig} \mathrm{u} \mathrm{r} \mathrm{e} \mathrm{3.} \mathrm{The} \mathrm{relative} \mathrm{importance} \mathrm{of} \mathrm{changes} \mathrm{in} \mathrm{the} \mathrm{gross} \mathrm{reproductive} \mathrm{rates}$ (GRR) and life expectancy at birth $\left(\mathrm{e}_{\mathrm{o}}\right)$ in influencing Aland's growth rates.
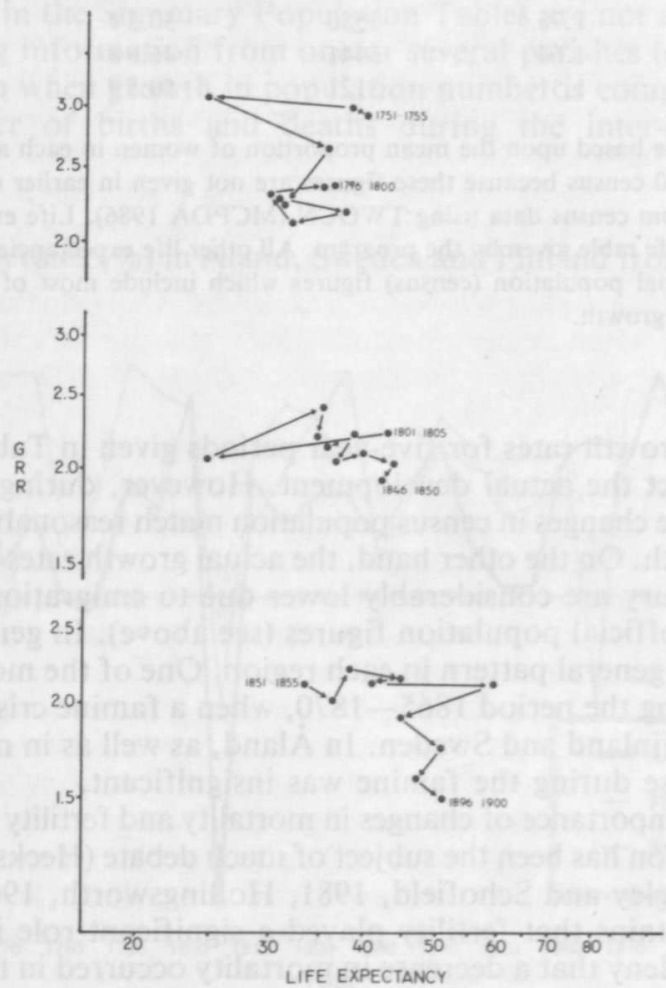
F i g u r e 4. Simplified representation of the proportional changes in mortality and fertility in Åland.

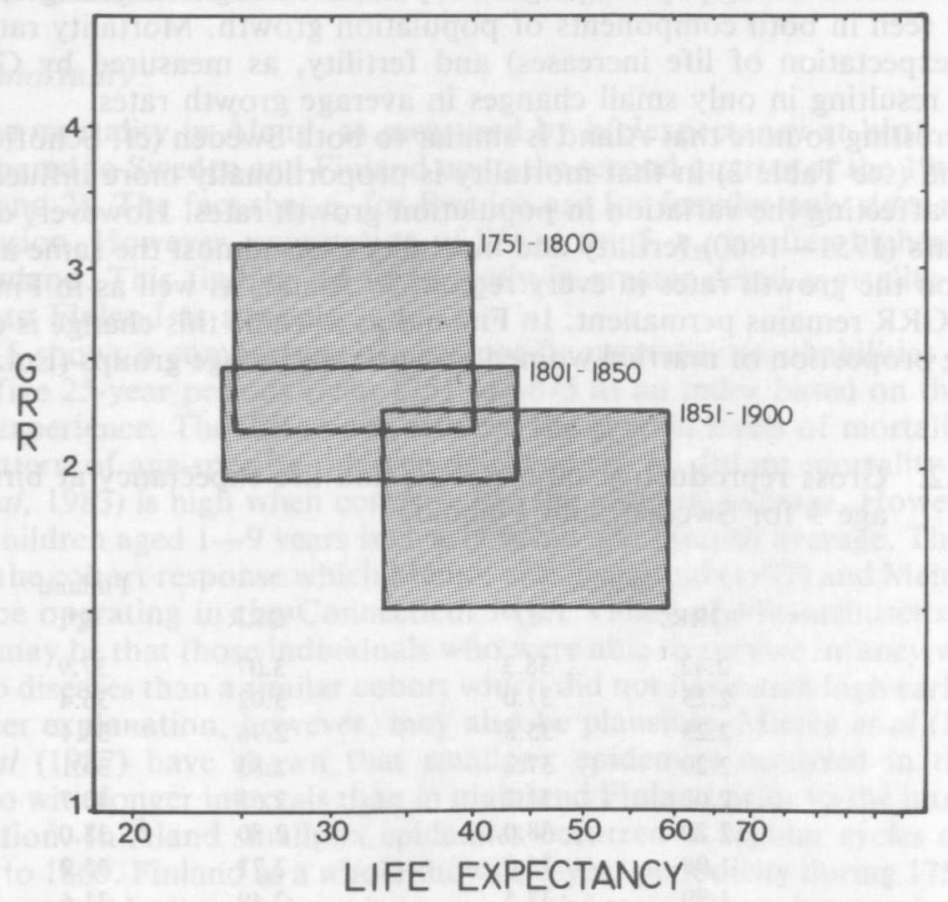

survive to the end of the childbearing period. It should be kept in mind that both TFR and GRR are hypothetical quantities that pertain to standardized conditions.

By graphing both GRR and $e_{o}$ on logarithmic scales the roles of fertility and mortality in influencing the growth rates of Aland from 1750 to 1900 can be evaluated (Figure 3). As Schofield (1984) points out, the changes that can be documented in this manner are not absolute, but are proportional; and there is some loss of precision. The 151-year time period has been divided into three parts: $1750-1799$, $1800-1849$, and $1850-1900$. These periods were chosen primarily because of their convenient length.

As can be seen in the upper-most section of Figure 3 there are considerable temporal changes in both fertility and mortality over this first 50 -year period. However, there is proportionally slightly more variation in mortality than in fertility. That is, the horizontal movement (temporal changes in life expectancy) is greater than the vertical movement (temporal changes in the GRR). There is relatively little change in fertility from 1750 to 1765 when compared to mortality. There is then a decrease in GRR starting in about 1765 when it goes to about 2.2 and remains at this level from 1775 to 1799 . This drop and relative stability in fertility is mirrored by only slight changes in mortality from 1775 to 1799 . From 1800 to 1849 the majority of the variation in growth is accounted for by changes in mortality and not fertility. Even discounting the war period (1808-09), there is more horizontal than vertical movement. The period from 1850 to 1900 is characterized by two major components. From 1850 to 1880 almost all of the change in population growth can be attributed to changes in mortality. Then from 1880 to 1900 there is relatively more change in the GRR than in $e_{\mathrm{o}}$. However, the decline in the GRR is primarily due to the problems in the population statistics described above.

When the three periods in Alland are compared in »box» fashion (Figure 4) in which the minimums and maximums of both GRR and $e_{0}$ are graphed, it is easy to 
visualize the changing patterns of both mortality and fertility over time. Concerning short-term variations Aland follows the conventional pattern in which mortality plays a primary role in affecting population growth patterns. Long-term changes, however, are clearly seen in both components of population growth. Mortality rates clearly decrease (expectation of life increases) and fertility, as measured by GRR, also decreases, resulting in only small changes in average growth rates.

It is interesting to note that Åland is similar to both Sweden (cf. Schofield, 1984) and Finland (see Table 2) in that mortality is proportionally more influential than fertility in affecting the variation in population growth rates. However, during the first 50 years $(1751-1800)$ fertility and mortality exert almost the same amount of influence on the growth rates in every region. In Aland, as well as in Finland, the decline in GRR remains permanent. In Finland as a whole this change is caused by a declining proportion of married women in reproductive age groups (Lutz and Pit-

$\mathrm{T} \mathrm{a} \mathrm{b} \mathrm{l} \mathrm{e} \mathrm{2.} \mathrm{Gross} \mathrm{reproductive} \mathrm{rates} \mathrm{(GRR)} \mathrm{and} \mathrm{life} \mathrm{expectancy} \mathrm{at} \mathrm{birth} \mathrm{and} \mathrm{at}$ age 5 for Sweden, and Finland.

\begin{tabular}{|c|c|c|c|c|c|}
\hline \multirow[b]{2}{*}{ Year } & \multicolumn{2}{|c|}{ Sweden } & \multicolumn{3}{|c|}{ Finland } \\
\hline & 'GRR & $e_{0}^{2}$ & ${ }^{3} \mathrm{GRR}$ & $e_{0}^{4}$ & $e_{5}^{4}$ \\
\hline $1751-1755$ & 2.42 & 38.3 & 3.07 & 37.9 & 50.7 \\
\hline $1756-1760$ & 2.25 & 37.0 & 3.02 & 36.4 & 49.2 \\
\hline $1761-1765$ & 2.23 & 35.8 & 2.96 & 33.1 & 47.5 \\
\hline $1766-1770$ & 2.20 & 37.2 & 2.83 & 36.1 & 49.0 \\
\hline $1771-1775$ & 2.02 & 31.2 & 2.63 & 40.7 & 50.9 \\
\hline $1776-1780$ & 2.20 & 38.0 & 2.80 & 38.0 & 51.0 \\
\hline $1781-1785$ & 1.98 & 36.0 & 2.71 & 35.9 & 49.5 \\
\hline $1786-1790$ & 1.99 & 37.5 & 2.49 & 31.6 & 42.1 \\
\hline $1791-1795$ & 2.12 & 39.5 & 2.59 & 33.7 & 46.6 \\
\hline $1796-1800$ & 2.10 & 39.1 & 2.49 & 39.7 & 51.9 \\
\hline $1801-1805$ & 2.02 & 41.0 & 2.51 & 38.6 & 50.4 \\
\hline $1806-1810$ & 1.96 & 33.7 & 2.23 & 26.9 & 37.8 \\
\hline $1811-1815$ & 2.08 & 37.5 & 2.34 & 35.2 & 47.7 \\
\hline $1816-1820$ & 2.12 & 41.0 & 2.31 & 37.7 & 49.0 \\
\hline $1821-1825$ & 2.31 & 43.7 & 2.43 & 37.4 & 49.4 \\
\hline $1826-1830$ & 2.23 & 42.5 & 2.41 & 39.0 & 50.3 \\
\hline $1831-1835$ & 2.22 & 43.1 & 2.19 & 31.6 & 42.7 \\
\hline $1836-1840$ & 2.12 & 43.4 & 2.13 & 37.6 & 48.0 \\
\hline $1841-1845$ & 2.14 & 45.8 & 2.32 & 41,3 & 51.7 \\
\hline $1846-1850$ & 2.05 & 45.0 & 2.30 & 39.2 & 49.7 \\
\hline $1851-1855$ & 2.04 & 44.2 & 2.40 & 35.2 & 46.0 \\
\hline $1856-1860$ & 2.16 & 43.3 & 2.33 & 34.3 & 45.2 \\
\hline $1861-1865$ & 2.18 & 45.8 & 2.46 & 37.2 & 49.7 \\
\hline $1866-1870$ & 2.01 & 45.4 & 2.08 & 27.3 & 37.8 \\
\hline $1871-1875$ & 2.13 & 48.0 & 2.39 & 41.6 & 52.5 \\
\hline $1876-1880$ & 2.14 & 47.9 & 2.42 & 40.9 & 51.4 \\
\hline $1881-1885$ & 2.06 & 50.0 & 2.36 & 41.3 & 51.9 \\
\hline $1886-1890$ & 2.02 & 52.5 & 2.40 & 44.4 & 53.1 \\
\hline $1891-1895$ & 1.94 & 52.5 & 2.27 & 43.4 & 52.6 \\
\hline $1896-1900$ & 1.91 & 54.2 & 2.35 & 45.7 & 53.8 \\
\hline
\end{tabular}

1 Based on TFRs given by Hofsten and Lundström (1976). Proportion of female births obtained from Historisk statistik I (1955).

${ }^{2}$ Life expectancy for females. From 1751 to 1850 figures taken from Schofield (1984). Figures from 1851 to 1900 were estimated on the basis of Figure 3.8 in Hofsten and Lundström (1976).

${ }^{3}$ GRRs from 1751 to 1775 are simple extrapolation estimates based on changes in the CBRs (these figures probably underestimate the actual figures in the 1750s and 1760s). GGRs from 1776 to 1865 based on TFRs given by Turpeinen (1979). Those from 1866 to 1900 are from Fougstedt (1977).

${ }^{4}$ Life expectancy for both sexes combined. Based on age-specific mortality rates obtained from Turpeinen (1973). 
känen, 1987). We can anticipate a similar change in Åland, since the average number of women over 15 years of age who were married was $62 \%$ from 1754 through 1769 , whereas the average was $57 \%$ from 1772 through 1805 .

\section{Levels of mortality}

Average mortality in Åland, as measured by life expectancy at birth, is higher when compared to Sweden and Finland up to the second quarter of the 19th century (Tables 1 and 2). The fact that $\mathrm{e}_{\mathrm{o}}$ for Sweden are for females only does not affect this conclusion. However, expectation of life at age $5, \mathrm{e}_{5}$, is often higher in Aland than in Finland. This finding led us to study in greater detail mortality in Åland compared to Finland as a whole.

Figure 5 shows a comparison of age-specific mortality (probabilities of dying, ${ }_{n} q_{x}$ ) from five 25-year periods from 1751 to 1875 as an index based on the Finnish mortality experience. The difference between the general levels of mortality varies, but the pattern of age-specific differences is consistent. Infant mortality in Aland (Trapp et al, 1983) is high when compared to the national average. However, mortality for children aged $1-9$ years is clearly below the Finnish average. This pattern resembles the cohort response which Meindl and Swedlund (1977) and Meindl (1979) found to be operating in the Connecticut River Valley of Massachusetts. The explanation may be that those individuals who were able to survive infancy were more resistant to diseases than a similar cohort which did not have such high early mortality. Another explanation, however, may also be plausible. Mielke et al (1984) and Jorde et al (1987) have shown that smallpox epidemics occurred in the Aland archipelago with longer intervals than in mainland Finland prior to the introduction of vaccination. In Aland smallpox epidemics occurred in regular cycles of 7 years from 1750 to 1800 . Finland as a whole shows a 5-year periodicity during 1751-1824. Since communicable diseases have been one of the main determinants of child mortality, it is plausible that the relative isolation of Aland and its low population density has led to lower childhood mortality, despite the fact that the epidemics, when they reached the archipelago, were sometimes exceptionally severe.

Another major feature which emerges from this comparison is the rather high probability of death in Åland for young adults. In fact, during certain periods $(1751-75$, and $1801-25){ }_{n} q_{x}$ values are higher in the archipelago when compared to mainland Finland. We initially proposed four hypotheses to account for this pattern. One of these, tuberculosis (consumption), we have rejected since data presented by Backman and Savonen (1934) show that mortality from tuberculosis has not been above the national average in Aland. The other three hypotheses, however, focus on factors which may have contributed, to some extent at least, to higher death probabilities. First, accidents, mainly cases of drowning, have been exceptionally numerous in Aland (Turpeinen, 1972). Second, the relative isolation of the Alland archipelago may have led to lower childhood mortality, but also to lower levels of immunity among older children and young adults, exposing them to infectious diseases. The level of exposure was thus higher when the epidemics finally reached Aland. Third, malaria mortality has been exceptionally high in the archipelago, affecting both children and adults. The number of malaria deaths was very high from 1751 to 1775 (Stigzelius, 1864), during the same period when mortality of young adults clearly exceeded the national average. In the case of malaria, Aland's population density and relative isolation were not advantageous because this infectious disease is not communicable but vector borne. In fact, malaria was endemic in the archipelago, especially in the main island, Fasta Aland, which had many swamps and ponds with standing water.

\section{Aland in relation to Finland and Sweden}

As shown in the analysis of GRR and life expectancy, the dynamics of the growth of Aland's population is somewhat similar to that of Sweden and Finland in that 
F i g u r e 5. Index of age-specific mortality (probability of dying) in Aland when mortality in Finland $=1$.
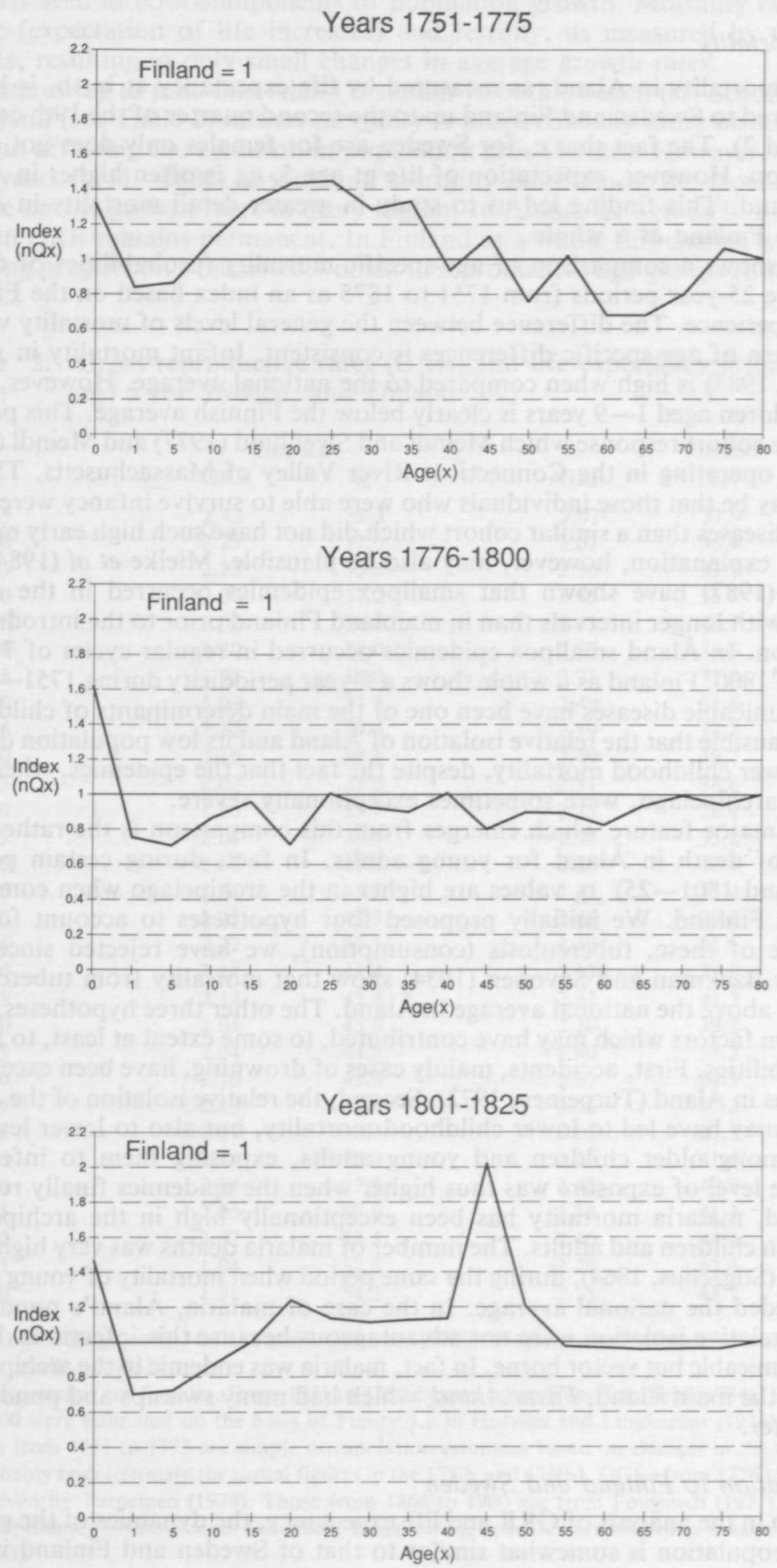

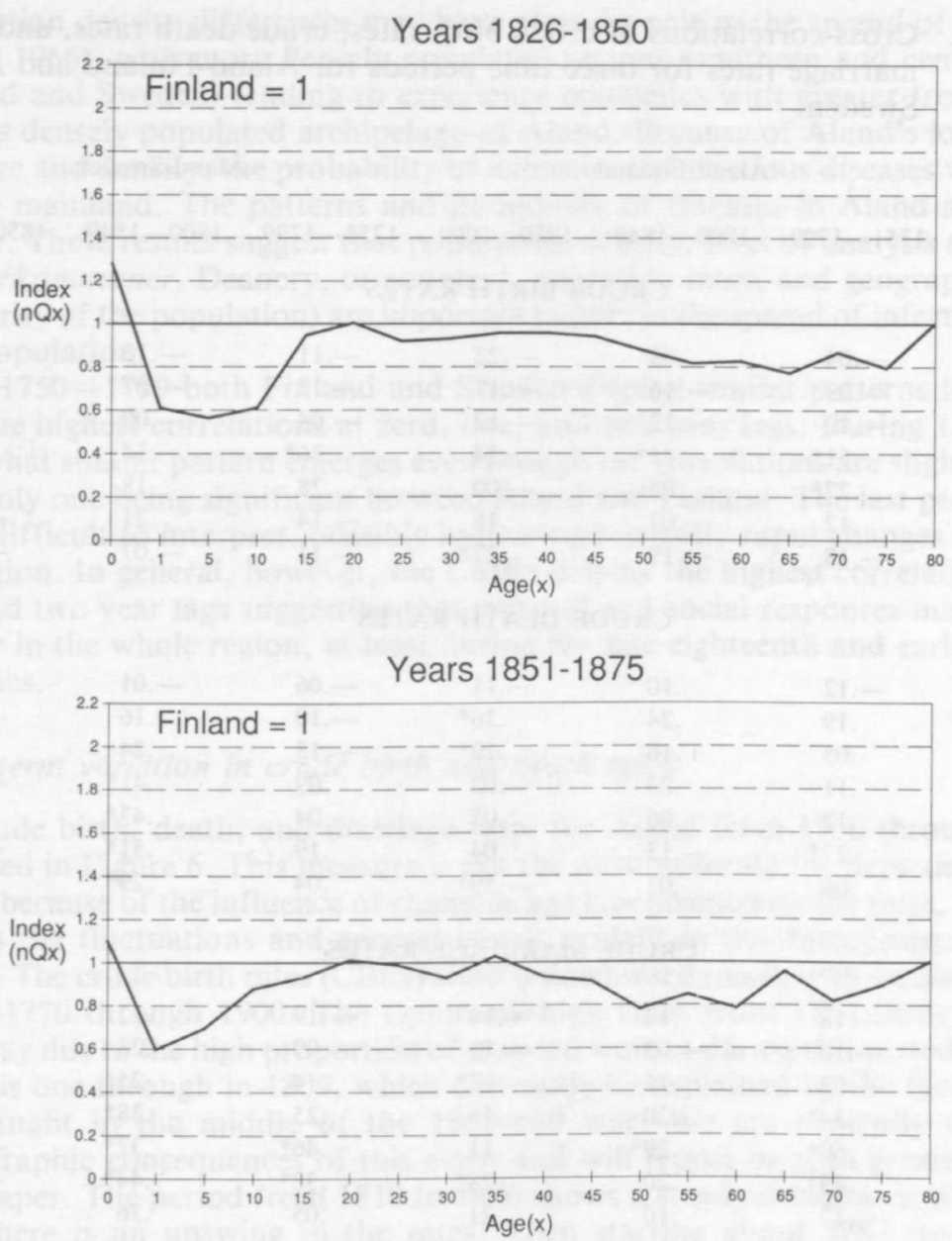

mortality varies relatively more than fertility. To further explore the relationship between Åland and Sweden and between Åland and Finland, cross-correlation analysis was conducted focusing upon the annual crude rates in each area. Theoretically we can envision a situation in which epidemics could spread from Sweden to Åland and then on to Finland, or vice versa. Under these conditions, the epidemics may move rapidly enough to affect all areas simultaneously or, more likely, they may take longer to spread from region to region causing some areas to »lag» behind others. Similarly, social and/or economic conditions could be influential in stimulating similar patterns in marriages or births throughout the region, although it is more plausible that these factors affect the overall levels of fertility and nuptiality rather than the year to year variation. To examine these possibilities, cross-correlations lagged by a maximum of three years have been run on the crude birth, death, and marriage rates for the three time periods.

Table 3 presents the cross-correlations by periods for Åland and Finland and for Åland and Sweden. The CBR correlations in 1751-1799 are similar for both ÅlandFinland and Alland-Sweden in that the highest correlation is at zero years lag, suggesting that $\mathrm{CBRs}$ are high (or low) in all regions at the same time. There is also a one-year lag effect occurring with Åland trailing both Finland and Sweden. The correlation between Alland and Sweden is, however, not statistically significant. During $1800-1849$ the zero lag correlation remains only for Finland, and there are no sig- 
T a b l e 3. Cross-correlations of crude birth rates, crude death rates, and crude marriage rates for three time periods for Ảland-Finland and ÅlandSweden.

\begin{tabular}{|c|c|c|c|c|c|c|}
\hline \multirow{2}{*}{$\begin{array}{l}\text { Áland } \\
\text { Lead-lag }\end{array}$} & \multicolumn{3}{|c|}{ Åland-Finland } & \multicolumn{3}{|c|}{ Äland-Sweden } \\
\hline & $1751-1799$ & $1800-1849$ & $1850-1900$ & $1751-1799$ & $1800-1849$ & $1850-190$ \\
\hline & \multicolumn{5}{|c|}{ CRUDE BIRTH RATES } & \\
\hline$E+3$ & -.04 & .03 & -.22 & -.11 & -.16 & -.12 \\
\hline$A+2$ & -.23 & -.16 & -.17 & -.12 & -.07 & -.04 \\
\hline$D+1$ & -.10 & -.12 & -.12 & -.08 & -.09 & -.03 \\
\hline 0 & $.51^{*}$ & $.45^{*}$ & .14 & $.36^{*}$ & .14 & $.52^{*}$ \\
\hline$L-1$ & $.27^{*}$ & .08 & -.00 & .28 & .18 & .00 \\
\hline A -2 & .12 & -.07 & .16 & -.14 & .21 & -.23 \\
\hline$G-3$ & -.18 & -.19 & $.27^{*}$ & -.11 & -.07 & -.17 \\
\hline
\end{tabular}

\section{CRUDE DEATH RATES}

L

$\begin{array}{rrrrrrr}\mathrm{L} & & & & & \\ \mathrm{E}+3 & -.12 & .10 & -.11 & -.06 & -.01 & .35^{*} \\ \mathrm{~A}+2 & .19 & .24 & .36^{*} & -.10 & .16 & -.01 \\ \mathrm{D}+1 & .03 & .16 & .29^{*} & -.13 & .24 & .22 \\ 0 & .11 & .23 & -.02 & .09 & .41^{*} & -.28^{*} \\ \mathrm{~L}-1 & .12 & .06 & .05 & -.04 & .43^{*} & .13 \\ \mathrm{~A}-2 & .27^{*} & -.13 & .04 & .19 & .51^{*} & -.13 \\ \mathrm{G}-3 & .06 & .03 & -.39^{*} & .04 & .29^{*} & .06\end{array}$

\begin{tabular}{rrrrrrr}
\multicolumn{7}{c}{ CRUDE MARRIAGE RATES } \\
$\mathrm{L}$ & \multicolumn{7}{c}{} & \\
$\mathrm{E}+3$ & -.18 & .14 & -.14 & -.19 & .12 & -.13 \\
$\mathrm{~A}+2$ & -.10 & -.03 & -.13 & -.09 & .23 & -.02 \\
$\mathrm{D}+1$ & -.02 & .15 & $-.27^{*}$ & .14 & .25 & $.27^{*}$ \\
0 & $.34^{*}$ & .20 & -.16 & .25 & $.38^{*}$ & .08 \\
$\mathrm{~L}-1$ & $.60^{*}$ & $.29^{*}$ & .11 & $.46^{*}$ & $.37^{*}$ & -.01 \\
$\mathrm{~A}-2$ & $.43^{*}$ & .20 & $.28^{*}$ & $.32^{*}$ & $.44^{*}$ & -.06 \\
$\mathrm{G}-3$ & .17 & .10 & .21 & .05 & .36 & .24
\end{tabular}

* Significant at the .05 level.

nificant correlations for Åland-Sweden. In 1850-1900 the pattern switches, with Åland-Sweden showing a significant zero lag correlation and Aland-Finland displaying one with Alland lagging 3 years. In general the crude birth rates are responding as predicted with little or no lag among the areas, except for the last period that shows a 3-year lag. These results suggest that conditions affecting annual variation in CBRs were rather similar in these areas.

For the CDRs in 1750-1799 there is one significant (although not very high) correlation at a 2-year lag between Ảland and Finland and no significant correlations between Åland and Sweden. Then from 1800-1849 the pattern changes rather dramatically with relatively high correlations appearing between Aland and Sweden at zero, one, two, and three year lags, while no significant correlations occur between Ảland and Finland. In 1850-1900 there is no clear configuration. Alland and Sweden show two significant correlations, one at zero lag and the other with Ảland leading Sweden by 3 years. Finland and Åland show, on the other hand, a very different pattern with Aland leading Finland by 1 and 2 years and also lagging Finland by 3 years (the correlation is negative, however). The CDRs do not appear to follow a very consistent pattern that would suggest the uniform spread of infectious diseases from Finland and Sweden to Aland. There is only one time period (1800-49) where the predicted lagged pattern appears between Aland and Sweden. As discussed above 
population density differences may have played a role in the spread of diseases (cf. Black, 1966), with more densely populated regions (southern and central parts of Finland and Sweden) tending to experience epidemics with greater frequency than the less densely populated archipelago of Ảland. Because of Åland's lower population size and density, the probability of exposure to infectious diseases was less than on the mainland. The patterns and periodicity of diseases in Aland appear to be unique. These results suggest that population density, level of analysis (e.g., church parish/kommuner, Deanery, or country), migration rates, and geographic location (insularity of the population) are important factors in the spread of infectious diseases in a population.

In 1750-1799 both Finland and Sweden display similar patterns in the CMRs with the highest correlations at zero, one, and two year lags. During 1800-1849 a somewhat similar pattern emerges even though the correlations are slightly different with only one being significant between Aland and Finland. The last period is again more difficult to interpret, possibly indicating relatively rapid changes occurring in the region. In general, however, the CMRs display the highest correlations at zero, one and two year lags suggesting that cultural and social responses may have been similar in the whole region, at least during the late eighteenth and early nineteenth centuries.

\section{Short-term variation in crude birth and death rates}

Crude birth, death, and marriage rates for Åland from 1750 through 1900 are provided in Figure 6. This measure is not the most accurate for depicting long-term trends because of the influence of changing age composition on the rates, but it clearly depicts the fluctuations and general trends evident in the demographic history of Aland. The crude birth rates (CBRs) show a downward trend, with fluctuations, from about 1770 through 1900 . The extremely high rates from 1754 through 1769 are probably due to the high proportion of married women during this period (see above). There is one through in 1809 , which can easily be explained by the fact that Aland was caught in the middle of the 1808-09 war. We are presently studying the demographic consequences of this event and will report on it in greater detail in a later paper. The period from 1810 to 1850 shows a steady decrease in the CBRs and then there is an upswing in the rates. Then starting about 1867 we see a rapid downward swing in the CBRs. Variation in the CBRs, as measured by coefficient of variation, averaged $14.4 \%$ during the 151 -year period showing no consistent change over time.

The crude death rates fluctuate dramatically when compared to either the birth or marriage rates. Mortality decreases in intensity, as measured by the CDRs, over the time period from 1750 to 1900 as seen in Figure 6. Variation in the CDRs was high during the first 50 years (coefficient of variation $=25.3 \%$ ) and punctuated with numerous mortality peaks. The variation decreased to $20 \%$ during the early 1800 s (supposing the $1808-1809$ war period is excluded), and peak mortality appears to lessen. From 1850 to 1900 the variation, as measured by coefficient of variation, is $28.6 \%$, being accounted for by the extremely high value (46/1000 population) in 1854 and the rapid and definite decline in the CDRs starting about 1857. As measured by the coefficient of variation, the CDRs show the most yearly variation of all three measures.

The crude marriage rate does not change as much over time in contrast to the crude death and birth rates. Even with this lack of dramatic change over time the coefficient of variation for the CMRs (17.2\% from 1750 to 1900) slightly exceeds the coefficient for the CBR. There are fluctuations with low rates occurring in 1782 , $1789,1809,1846$, and 1855 . There are two peak periods, 1792-1794 and immediately after the war in 1810. The first peak may be responsible, to some degree, for the relatively high birth rates between 1792 and 1800 . The CMRs start to decrease dramatically in about 1864, about three years earlier than the decline in the CBRs. 
Even though these crude rates are not precise indicators because of possible changes in the age structure of the population, they do provide a basis for initiating an inquiry into the dynamics among vital events. In order to document longer-term changes while simultaneously detailing short-term fluctuations, we have constructed a measure that highlights periods of »extreme behavior». These are periods when vital events were either considerably lower or higher than predicted. In this manner a more detailed picture of Aland's population dynamics is provided.

\section{Periods of Extreme Behavior}

Historians and demographers are oftentimes captivated by extreme mortality peaks and tend to overlook periods of low mortality or relatively long periods of moderately high mortality. There is also a tendency to ignore the peaks and valleys in both marriage and birth time series. Much of this fascination with mortality crises has biased our understanding of the interaction of marriages, births and deaths. To understand the population dynamics of Åland better, an "Index of Extreme Behavior» (see chapter Materials and methods) was calculated for the crude birth, death, and marriage rates. This methodology not only allows for the examination of crisis periods in Alland, but it also provides a method to understand the temporal changes in the growth rates.

Figure 7 depicts the »Index of Extreme Behavior» for the crude rates in Aland from 1750 to 1900 . In general, the index shows much more variation in the death series than either the birth or marriage series, with the crude birth rate displaying the least amount of variation. The largest peaks in the death, birth, and marriage series are easily attributed to the $1808-09$ war period. High mortality is followed by the post-war increase in marriages and births. A somewhat similar pattern is seen after the peak mortality in 1789 . However, the same type of response to high mortality is not seen after other mortality peaks. High mortality in 1765 , for example, is not followed by any considerable increase in birth or marriage rates. This pattern suggests that in order to fully understand a mortality crisis, and its effects on population dynamics, one must also analyze the age structure of deaths (see e.g. Perrenoud, 1984). Both in 1789 and during the $1808-09$ war the adult population was also

F i g u r e 6. Crude birth, death, and marriage rates in Åland from 1750 to 1900.

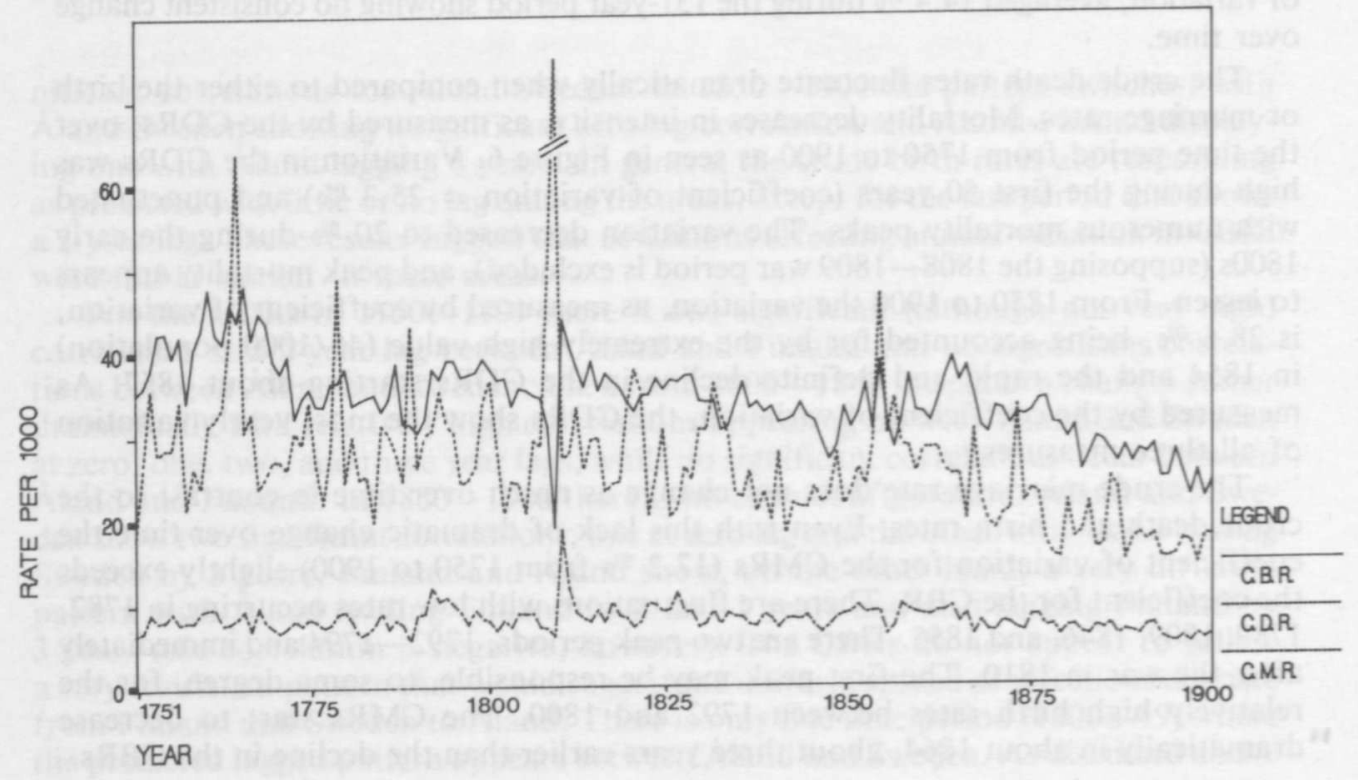


F i g u r e 7. Index of Extreme Behavior for crude birth rates (top), crude death rates (middle), and crude marriage rates (bottom).

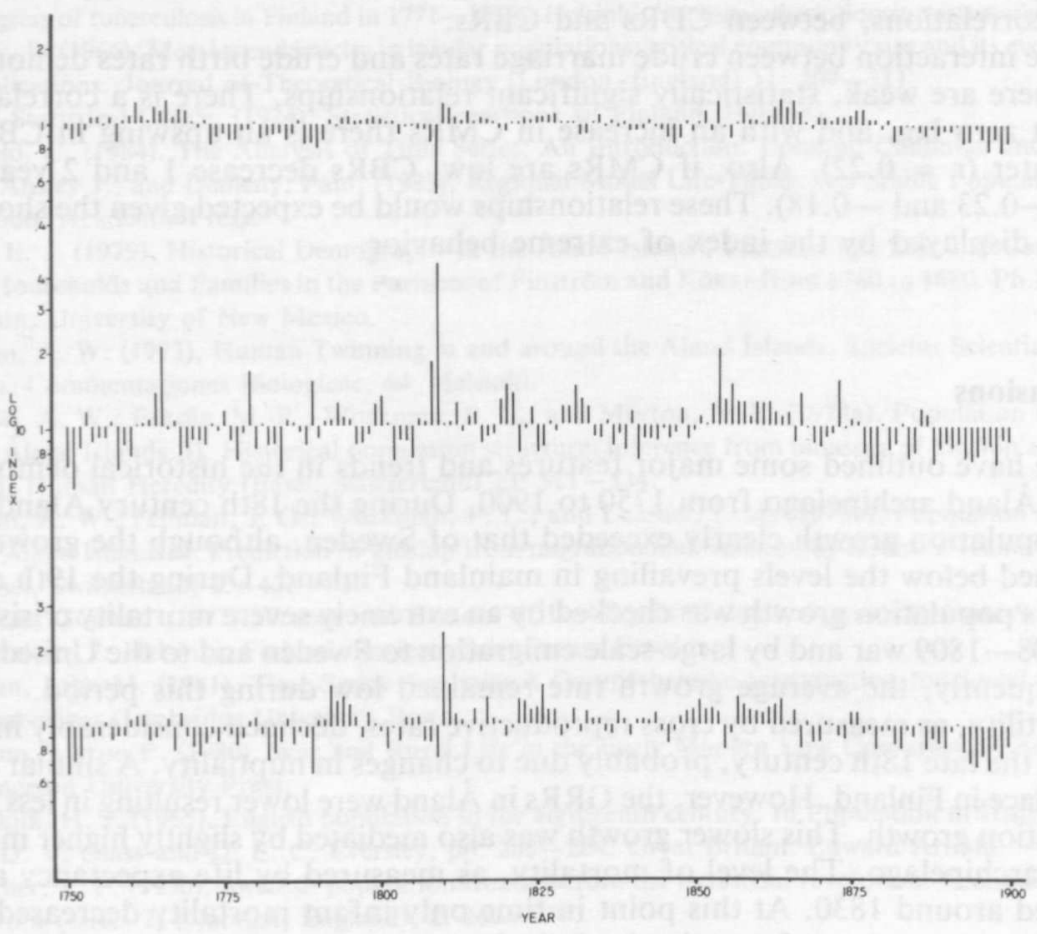

affected. Among the most important causes of death were typhoid, typhus, and relapsing fever. In 1789 , for example, »only» $33 \%$ of the deaths were among children less than 10 years of age. Nearly $15 \%$ of the existing marriages were dissolved. On the other hand, in $176558.5 \%$ of the deaths were due to smallpox, and $17.4 \%$ to unknown childhood diseases. Over $69 \%$ of the deaths were among children less than 10 years of age.

An interesting feature, as shown on the index, is a period of sustained, high mortality from 1853 to 1865 (from to 1853 to 1855 there were epidemics of scarlet fever and cholera). This death rate is coupled with a six year period of higher than predicted birth rate. Growth rates at the beginning of this time are low (about $0.07 \%$ ) and then increase to $1.07 \%$. After 1867 death rates drop except for one peak in 1873 (attributed mainly to smallpox and scarlet fever $-41 \%$ of the deaths), and finally there is major sustained drop that occurred in 1888. CBRs start to fall in 1877 and remain below the predicted value starting in 1882. Marriage rates also fall in 1878 . Life expectancy rises to about 50 years.

To understand the interactions among the vital rates in more detail, we also ran sliding cross-correlations between rates lagged from zero to five years. Most correlations were low with only a few being statistically significant. The results did, however, strengthen our impressions that were gained from the other analyses.

Crude marriage rates increase 3 years after crude death rates were high, but the correlation was only 0.20 and not statistically significant. This finding strengthens the argument that an understanding of the age structure of deaths during crisis periods is vital. For Aland, many of the periods of high mortality (extreme behavior) can be attributed to the very high child mortality rates, and the repercussions are different than would be expected if the mortality occurred among the reproductive segment of the population. Crude birth rates, on the other hand, are higher 1 year after high 
infant mortality $(r=0.23, p<0.05)$ suggesting that there may be some replacement strategy occurring. This hypothesis needs to be examined in greater detail, while taking into account other possible explanations. There is also no relationship, as shown by cross-correlations, between CDRs and CBRs.

The interaction between crude marriage rates and crude birth rates demonstrates that there are weak, statistically significant relationships. There is a correlation of 0.34 at zero lag, and with an increase in CMRs there is an upswing in CBRs one year later $(r=0.22)$. Also, if CMRs are low, CBRs decrease 1 and 2 years later $(\mathrm{r}=-0.23$ and -0.18$)$. These relationships would be expected given the short-term trends displayed by the index of extreme behavior.

\section{Conclusions}

We have outlined some major features and trends in the historical demography of the Åland archipelago from 1750 to 1900 . During the 18 th century Aland's relative population growth clearly exceeded that of Sweden, although the growth rates remained below the levels prevailing in mainland Finland. During the 19th century Aland's population growth was checked by an extremely severe mortality crisis during the 1808-1809 war and by large-scale emigration to Sweden and to the United States. Consequently, the average growth rate remained low during this period.

Fertility, as measured by cross reproductive rates, declined considerably in Aland during the late 18 th century, probably due to changes in nuptiality. A similar decline took place in Finland. However, the GRRs in Aland were lower resulting in less natural population growth. This slower growth was also mediated by slightly higher mortality in the archipelago. The level of mortality, as measured by life expectancy at birth declined around 1830 . At this point in time only infant mortality decreased, while life expectancy at age 5 remained relatively constant.

The pattern of age-specific mortality in Aland was unique when compared to mainland Finland. Infant mortality was very high, but mortality among children (ages 1 through 9) was relatively low. Conditions of high infant mortality may have played a major role in the life expectancies of children in Aland in that those who survived had higher life expectancies. On the other hand, the longer periods between epidemic diseases may have contributed significantly to this behavior. The longer periods are due to the relative isolation and low population density of Aland. However, this insularity and population structure did not mediate the effects of malaria mortality.

Future research will concentrate on specific aspects of Aland's demography in an attempt at clarification and testing of hypotheses regarding the nature of the differential patterns that are unique to Aland.

\section{Acknowledgements}

This research could not have been accomplished without the kind and generous help of many people. We would especially like to thank Mr. Bjarne Henriksson and his staff at the Landskapsarkivet, Aland, for their time and expertise. We are indebted to all of Aland's Lutheran ministers who allowed us to examine and copy selected archival sources. We also thank them for their kindness and hospitality. We thank Alland's Museum for their expert advice and counsel. Our appreciation is also extended to Ms. Margareta Damsten. We thank P. Genie Trapp for her help with the illustrations. This research was founded by grants from Sigrid Jusèlius Foundation, Helsinki, and the National Science Foundation (Grants BNS-83-19057 and BNS-83-19448). 


\section{References}

Backman, Wold.; and Savonen, Severi. (1934). Keuhkotaudin kulku Suomessa vuosina 1771-1929. (The progress of tuberculosis in Finland in 1771-1929). Helsinki: Suomen tuberkuloosin vastustamisyhdistys.

Black, F. L. (1966). Measles endemicity in insular populations: critical community size and its evolutionary implications. Journal of Theoretical Biology (London, England) 11: 207-211.

Central Statistical Office. (1924). Statistical yearbook of Finland. Helsinki.

Chatfield, C. (1984). The Analysis of Time Series: An Introduction. London: Chapman and Hall.

Coale, Ansley J.; and Demeny, Paul. (1983). Regional Model Life Tables and Stable Populations, 2nd edition. Academic Press.

Devor, E. J. (1979). Historical Demography in the Alland Islands, Finland: The Size and Composition of Households and Families in the Parishes of Finström and Kökar from 1760 to 1880. Ph.D. Dissertation, University of New Mexico.

Eriksson, A. W. (1973). Human Twinning in and around the Ảland Islands. Societas Scientiarum Fennica, Commentationes Biologicae, 64. Helsinki.

Eriksson, A. W.; Eskola, M.-R.; Workman, P. L.; and Morton, N. E. (1973a). Population studies on the Ảland Islands. II. Historical population structure: inference from bioassay of kinship and migration. Human Heredity (Basel, Switzerland) 23: 511-534.

Eriksson, A. W.; Fellman, J. O.; Workman, P. L.; and Lalouel, J. M. (1973b). Population studies on the Aland Islands. I. Prediction of kinship from migration and isolation by distance. Human Heredity (Basel, Switzerland) 23: 422-433.

Fougstedt, Gunnar. (1977). Trends and Factors of Fertility in Finland. Commentationes Scientiarum Socialum, 7. Helsinki, Finland: Societas Scientiarum Fennica.

Gottman, John M. (1981). Time-Series Analysis: A Comprehensive Introduction for Social Scientists. Cambridge: Cambridge University Press.

Gutmann, Myron P. (1980). War and Rural Life in the Early Modern Low Countries. Princeton, NJ: Princeton University Press.

Habakkuk, H. J. (1965). English population in the eighteenth century. In Population in History, edited by D. V. Glass and D. E. C. Eversley, pp. 269-284. Great Britain: Edward Arnold.

Heckscher, E. F. (1950). Swedish population trends before the industrial revolution. Economic History Review (series 2) (Norvich, England), 2: 266-277.

Historiallinen tilasto. (Historical statistics). (1983). Suomen taloushistoria (Economic history of Finland), edited by Kaarina Vattula. Helsinki: Tammi.

Historisk statistik I (1955). Historisk statistik för Sverige, Volume I, Befolkning 1720-1950. (Historical statistics of Sweden, Volume I, Population 1720-1950). Stockholm: Statistiska Centralbyrån.

Hofsten, Erland; and Lundström, Hans. (1976). Swedish Population History: Main Trends from 1750 to 1970 . Stockholm: Statistiska Centralbyrån.

Hollingsworth, Thomas H. (1969). Historical Demography. Ithaca, NY: Cornell University Press.

Jaatinen, S. (1960). Expansion and retreat of settlement in the southwestern archipelago of Finland. Fennia (Helšinki, Finland) 84: 39-65.

Jorde, L. B.; Workman, P. L.; and Eriksson, A. W. (1982). Genetic microevolution in the Ảland Islands, Finland. In Current Developments in Anthropological Genetics, vol. 2, edited by M. H. Crawford and J. H. Mielke, pp. 333-365. NY: Plenum Press.

Jorde, L. B.; Pitkänen, K.; Mielke, J. H.; Fellman, J. O.; and Eriksson, A. W. (1987). Historical Epidemiology of Smallpox in Kitee, Finland. (In press).

Lutz, Wolfgang; and Pitkänen, Kari. (1987). Tracing Back the Eighteenth Century »Nuptiality Transition" in Finland. (In press).

McCleary, Richard; and Hay Richard A., Jr. (1980). Applied Time Series Analysis for the Social Sciences. Beverly Hills, California: Sage Publications.

McKeown, Thomas. (1974). The Modern Rise of Population. London: Edward Arnold.

McKeown, Thomas. (1978). Fertility, mortality and cause of death. Population Studies (London, England) 32: $535-542$.

McKeown, Thomas; and Brown, R. G. (1955) Medical evidence related to English population changes in the eighteenth century. Population Studies (London, England) 9: 119-141.

MCPDA. (1986). Microcomputer Programs for Demographic Analysis. Demographic Data for Development Institute for Resource Development at Westinghouse. Columbia, Maryland.

Mead, W. R.; and Jaatinen, S. H. (1975) The Äland islands. London: David \& Charles.

Meindl, R. S. (1979). Environmental and Demographic Correlates of Mortality in 19th Century Franklin County, Massachusetts. Ph.D. Dissertation, University of Massachusetts, Amherst.

Meindl, R. S.; and Swedlund, A. C. (1977). Secular trends in the Connecticut Valley, 1700-1850. Human Biology (Detroit, USA) 49: 389-414.

Mielke, J. H.; Workman, P. L.; Fellman, J.; and Eriksson, A. W. (1976). Population structure of the 
Åland Islands, Finland. In Advances in Human Genetics, edited by H. Harris and K. Hirschhorn, pp. 241-321. NY: Plenum Press.

Mielke, J. H.; Devor, E. J.; Kramer, P. L.; Workman, P. L.; and Eriksson, A. W. (1982). Historical population structure of the Aland Islands, Finland. In Current Developments in Anthropological Genetics, vol 2, edited by M. H. Crawford and J. H. Mielke, pp. 255-332. NY: Plenum Press.

Mielke, J. H.; Jorde, L. B.; Trapp, P. G.; Anderton, D. L.; Pitkänen, K.; and Eriksson, A. W. (1984). Historical epidemiology of smallpox in Ảland, Finland: 1751-1890. Demography (Washington DC, USA) 21: $271-295$.

Mitchell, B. R. (1980). European Historical Statistics 1750-1970. NY: Columbia University Press.

Nerdrum, M. (1976). Kvinnan, familjen och det åländska samhället - en kohortstudie av kvinnor födda i Finströms socken åren 1760-62 samt 1840-42. (Woman, family, and society in the Ảland islands - a cohort study on women born in the parish of Finström in $1760-62$ and 1840-42). Thesis, Ảbo Akademi, Ảbo, Finland.

Nerdrum, M. (1978). Household structure in Finström parish, Ảland, 1760-62 and 1840-42. In Chance and Change, edited by S. Ảkerman, H. C. Johansen and D. Gaunt. Odense: Odense University Press.

Perrenoud, Alfred (1984). The mortality decline in a long-term perspective. In Pre-industrial Population Change, edited by T. Bengtsson, G. Fridlizius and R. Ohlsson, pp. 41-70. Sweden: Almquist \& Wiksell International.

Pitkänen, Kari. (1977). The reliability of the registration of births and deaths in the eighteenth and nineteenth centuries in Finland: some examples. Scandinavian Economic History Review (Odense, Denmark) 25: $138-159$.

Pitkänen, Kari. (1980). Registering people in a changing society - the case of Finland. Yearbook of Population Research in Finland 18: 60-79.

Pitkänen, Kari. (1984). The history of population registration and demographic data collection in Finland. National Population Bibliography of Finland 1945-1978. Pp. 11-17. IUSSP; Finnish Demographic Society.

Pitkänen, Kari. (1986). Viime vuosisadan vaihteen väestötilasto ja suomalaisten miesten kuolleisuus. (Population statistics at the turn of the last century and the mortality of Finnish men). Sosiaalilääketieteellinen Aikakauslehti (Helsinki, Finland) 23: 375-382.

Radloff, F. W. (1795). Beskrifning öfver Ảland. (Description on Ảland). Ảbo, Finland.

Schofield, R. S. (1984). Population growth in the century after 1750: the role of mortality decline. In Pre-industrial Population Change, edited by T. Bengtsson, G. Fridlizius and R. Ohlsson, pp. 17-39. Sweden: Almquist \& Wiksell International.

Sjölund, F. et al. (1972). Ảland-Mariehamn Guide. Kuultokuva, Helsinki.

Sokal, Robert R.; and Rohlf, F. James. (1969). Biometry. San Francisco: W. H. Freeman and Company.

Stigzelius, Lars Herman. (1864). Anteckningar om Malaria epidemierna på Ảland under senaste århundrade. (Notes on malaria epidemics in Ảland during the last century). Helsingfors, Finland.

Trapp, P. G.; Mielke, J. H.; Jorde, L. B.: and Eriksson, A. W. (1983). Infant mortality patterns in Ảland, Finland. Human Biology (Detroit, USA) 55: 131-149.

Turpeinen, Oiva. (1972). Haudanvakava elämä ja leikkivä kuolema. Suomen väestöoloista vv. 1816-1865. (Deadly serious life and playful death. On Finnish Population in 1816-1865). Helsinki, mimeographed.

Turpeinen, Oiva. (1973). Ikäryhmittäinen kuolleisuus Suomessa vv. 1751-1970. Demometrinen selvitys. (Age-specific mortality in Finland in 1751-1970. A demometric study). Helsinki, mimeographed.

Turpeinen, Oiva. (1979). Fertility and mortality in Finland since 1750. Population Studies (London, England) 33: $101-114$.

Wrigley, E. A.; and Schofield, R. S. (1981). The Population History of England 1541-1871: A Reconstruction. Cambridge, Massachusetts: Harvard University Press. 